ARTIKEL

\title{
Inovasi Pembangunan Desa Melalui Kepemimpinan Transformasional dan Catalytic Collaboration: \\ Belajar dari Keberhasilan Pengelolaan Taman Ghanjaran di Desa Ketapanrame, Mojokerto
}

\section{Village Development Innovations Through Transformational Leadership and Catalytic Collaboration:}

Learning From the Success of Ghanjaran Park Management in Ketapanrame Village, Mojokerto

\section{OPEN ACCESS}

Citation: Wahyuningsih, E., Noer S., \& Setia Yunas, N. (2021). Inovasi Pembangunan Desa Melalui Kepemimpinan Transformasional Dan Catalytic Collaboration: Belajar Dari Keberhasilan Pengelolaan Taman Ghanjaran Di Desa Ketapanrame, Mojokerto. Matra Pembaruan. 5(2), 141-152

Received: July 19, 2021

Accepted: November 03, 2021

Published: November 29, 2021

(c) The Author(s)

\section{(c) (i) (2) (2)}

This work is licensed under a Creative Commons Attribution-NonCommercialShareAlike 4.0 International License.

Kata Kunci: kepemimpinan transformasional, kolaborasi katalis, desa, BUMDES

Keywords: transformational leadership, catalytic collaboration, village, BUMDES

\author{
Endah Wahyuningsih (iD 1*, Shobirin Noer (iD) 2 , Novy Setia Yunas iD 3 \\ ${ }^{1}$ Program Studi Ilmu Sosiatri Fisipol Universitas Darul 'Ulum Jombang \\ ${ }^{2}$ Program Studi Ilmu Pemerintahan Fisipol Universitas Darul ‘Ulum Jombang \\ 1,2Jl. Gus Dur No.29A, Mojongapitindah, Mojongapit, Kec. Jombang, Kabupaten Jombang, Jawa Timur \\ 61419 \\ ${ }^{3}$ Program Studi Ilmu Politik FISIP Universitas Brawijaya Malang \\ ${ }^{3} \mathrm{Jl}$. Veteran, Ketawanggede, Kec. Lowokwaru, Kota Malang, Jawa Timur 65145 \\ $\square$ endahsetiyanto@gmail.com
}

Abstrak: Taman Ghanjaran yang berada di Desa Ketapanrame Trawas Mojokerto merupakan bagian dari unit usaha BUMDes yang berhasil dikelola dengan baik dan telah mendapatkan banyak penghargaan. Penelitian ini bertujuan untuk mengetahui bagaimana karakter kepemimpinan transformatif (transformational leadership) dan pendekatan kolaborasi katalis yang dibangun dalam keberhasilan pengelolaan BUMDES khususnya unit usaha Taman Ghanjaran. Metode penelitian ini adalah penelitian kualitatif. Pengumpulan data melalui wawancara, observasi langsung dan dokumen-dokumen yang terkait dengan pembangunan Wisata Ghanjaran. Data diperoleh melalui instrumen berupa wawancara mendalam (in depth interview). Terdapat 7 narasumber dalam penelitian ini, yang terdiri atas kepala desa, staf BUMDesa, pelaku usaha, dan staf desa. Analisa data menggunakan metode induktif. Hasil penelitian menunjukkan bahwa keberhasilan dari Unit Usaha BUMDEs Desa Ketapanrame khususnya Wisata Ghanjaran sampai mendapatkan penghargaan baik di tingkat lokal, provinsi sampai dengan nasional tidak lepas dari peran kepala desa. Kepala Desa Ketapanrame memiliki peran yang sentral mulai dari perencanaan (bersama BPD melahirkan Peraturan Desa-Peraturan Desa (perdes-perdes) terkait tata kelola aset desa), melakukan assessment pada potensi desa, sampai dengan keberhasilan memberdayakan masyarakat dengan terus meningkatnya partisipasi banyak pihak. Ketokohan dan visi kepala desa juga menjadi tauladan masyarakat luas dengan nilai-nilai yang dimilikinya antara lain jujur, terbuka, peduli terhadap sesama, tanggung jawab dan amanah.

\begin{abstract}
Ghanjaran Park, which is located in Ketapanrame Trawas Village, Mojokerto, is part of the BUMDes business unit which has been successfully managed and has received many awards. This study aims to determine how the role of transformational leadership of village head in the governance of Ghanjaran Park is. This study used qualitative research methods. Data was collected by interviews, direct observation and documents related to the development of Ghanjaran Park. The data was obtained by using an in-depth interview instrument. There were 7 informants in this study, consisting of village heads, BUMDes staff, business actors, and village staff. Data analysis using inductive method. The results showed that the success of the BUMDEs in Ketapanrame Village, especially Ghanjaran Park, to get awards at the local, provincial and national levels could not be separated from the role of the village head. The village head of Ketapanrame has a central role, starting from planning (with the BPD creating village regulations related to village asset management), conducting an assessment of the potential of the village, to the success of empowering the community by increasing the participation of many parties. The village head's character is also a role model for the wider community with its values, including honesty, openness, caring for others, responsibility and trust.
\end{abstract}




\section{Pendahuluan}

Indonesia terdiri dari 34 Provinsi, 514 kabupaten, 7.252 kecamatan, 83.820 desa (BPS semester 2 Tahun 2019). Jumlah desa yang banyak itu merupakan potensi yang luar biasa untuk dikembangkan guna tercapai kesejahteraan sesuai amanah UndangUndang Dasar. Pergeseran model pembangunan dari top down menjadi buttom up ini membuat berubah model dan strategi pembangunan di negara kita, akan tetapi perubahan ini tidak akan berhasil ketika masyarakat tidak siap menjadi subjek/ pelaku dalam proses pembangunan.

Sejak diberlakukannya Undang-Undang Desa nomor 6 Tahun 2012 ini memberikan tanggung jawab yang besar pada pemerintah desa untuk mengelola dana tersebut dengan baik menuju desa yang sejahtera dan mandiri. Desa dituntut untuk terus mengasah kemampuan dan meningkatkan partisipasi masyarakatnya. Selain itu hal yang tidak kalah penting adalah pemerintah desa harus memiliki kemampuan dalam menggali potensi desa. Hal ini menjadi penting adanya karena dengan assessment yang benar untuk menggali informasi terkait potensi desa maka desa akan mengetahui kekuatan dan kemampuan yang dimiliki dan akan dikembangkan. Hal ini merupakan modal dasar dalam memanfaatkan peluang-peluang yang ada.

Modal sosial telah diperdebatkan secara luas dan telah menjadi topik terkait pembangunan yang populer, pertama kali disebutkan dalam studi Robert D Putnam (1993,1995, 2002), James Coleman (1990, 1998), Fukuyama (1999, 2002), dan bahkan Adam Smith dalam kajian ekonominya juga unsur modal sosial dalam studinya tentang ekonomi yang disebut dengan "social contract", yaitu social network, suatu pola hubungan yang menentukan keberhasilan kemajuan dalam pembangunan ekonomi.

Fukuyama menegaskan pada perluasan dimensi, yaitu suatu kondisi yang menyebabkan orang berkumpul dalam mencapai tujuan bersama berdasarkan persatuan maupun tunduk pada nilai dan norma yang tumbuh dan dipatuhi. Sikap berpartisipasi, saling memperdulikan, memberi maupun menerima, saling percaya merupakan nilai dan norma yang menjadi ruh dari modal sosial (Fukuyama, 2001).

Standar sosial yang digunakan sebagai acuan dalam perilaku dalam kelompok sosial adalah Norma. Norma sosial berasal dari nilai-nilai sosial yang telah disepakati dalam kelompok. Norma yang muncul secara alami dan telah ada sejak lama pada umumnya akan terinternalisasi ke dalam perilaku kelompok dan terintegrasi ke dalam norma pribadi yang akan mengatur perilaku mereka. Dalam kondisi tertentu, jika norma tidak sesuai dengan norma pribadi, anggota kelompok/organisasi cenderung tidak mengikutinya. Tingkat kepatuhan setiap individu terhadap aturan sangat subjektif tergantung pada kesesuaiannya untuk individu orang tersebut. Dalam konteks pembangunan, perlu diperhatikan adanya standar.

Perlawanan juga bisa muncul karena ide dan nilai tidak terkandung dalam norma bersama. Norma dalam suatu kelompok/organisasi efektif apabila dapat menginspirasi anggotanya untuk menaatinya atau bahkan sesuai dengan norma pribadi. Aturan seperti ini menjadi modal sosial bagi anggota kelompok. Standar yang dapat dijadikan modal sosial adalah standar yang didukung oleh anggota dan dapat meningkatkan kerjasama antar anggota.

Modal sosial memiliki ukuran yang cukup luas. Pada hakekatnya modal sosial merupakan investasi dalam memperoleh sumber daya baru. Modal sosial dapat dilihat dari potensi suatu kelompok, dari model hubungan/ hubungan (antar individu atau antar kelompok) dengan memperhatikan nilai dan norma yang berlaku.

Community capital mempengaruhi keberhasilan pembangunan, antara lain Human Capital, Produced Economic Capital, Natural Capital and Social Capital/ modal sosial. Modal sosial merupakan bagian dari modal komunitas yang menitikberatkan pada kerjasama masyarakat untuk meningkatkan kualitas hidup yang berlandaskan pada nilai dan norma, dan yang menjadi unsur utamanya adalah kepercayaan/ trust, timbal balik, aturan kolektif yang ada dalam masyarakat,

1. Kemampuan Personal (Human Capital) meliputi pendidikan, pengetahuan, kesehatan, keahlian, kesehatan dan keadaan terkait lainnya. 
2. Aset Ekonomi (Produced Economic Capital) meliputi sumberdaya dan asset finansial Adanya pemerataan pada distribusi pangan.

3. Modal Sosial (Social Capital) yang meliputi nilai, norma, trust, reciprocity dan nilai sosial lainnya

4. Modal Alam (Natural Capital) meliputi sinar matahari, air, flora, energy, tanah, pemandangan alam dan lain-lain (Hasbullah, 2006).

Program pembangunan yang digagas oleh Kementerian Desa, Pembangunan Daerah Tertinggal dan Transmigrasi bekerjasama dengan Kementerian Pariwisata dan Ekonomi Kreatif sedang giat-giatnya mengkampanyekan program wisata desa untuk dilaksanakan pada desa-desa yang memiliki potensi untuk dikembangkan menjadi desa wisata. Program ini banyak diadopsi dan dilaksanakan oleh kepala desa. Selain itu, ada beberapa aspek yang harus diperhatikan supaya program desa wisata dapat berhasil. Menurut Medlik, yang dimuat dalam Ariyanto (2005), ada empat aspek yang harus diperhatikan dalam penawaran pariwisata. Aspek-aspek tersebut adalah sebagai berikut:

Pertama, attraction (daya tarik) dimana Daerah Tujuan Wisata (selanjutnya disebut DTW) memiliki daya tarik, baik daya tarik berupa alam maupun masyarakat dan budaya untuk menarik wisatawan. Semua ciptaan Tuhan Yang Maha Esa, yang ditemukan dalam bentuk kondisi alam, flora dan fauna, seperti: pemandangan alam, panorama indah, hutan rimba dengan tumbuhan hutan tropis, dan binatang-binatang langka. Selain itu, karya manusia yang berwujud museum, peninggalan purbakala, peninggalan sejarah, seni budaya, wisata agro (pertanian), wisata tirta (air), wisata petualangan, taman rekreasi, dan tempat hiburan juga merupakan daya tarik wisata.

Kedua, Accessibility (aksesibilitas), dimaksudkan untuk mempermudah dalam pencapaian tujuan ke tempat wisata bagi wisatawan domestik maupun mancanegara meliputi: jaringan jalan model Transportasi maupun Pendukung Transportasi (tempat parkir, penerangan jalan, signage, dan lain-lain.

Ketiga, amenities (fasilitas), merupakan salah satu syarat daerah tujuan wisata agar wisatawan dapat tinggal lebih lama di kawasan wisata. Dengan melihat dua aspek akomodasi dan utilities. Akomodasi merupakan fasilitas penginapan, fasilitas tempat makan/ restoran, fasilitas pelayanan kesehatan, fasilitas pelayanan keuangan, fasilitas perbelanjaan). Sedangkan utilities adalah dapat dilihat dari ketersediaan penyediaan air bersih, jaringan listrik, sistem drainase, sistem pengolahan limbah dan sanitasi, telekomunikasi, persampahan.

Keempat, ancillary (kelembagaan) berkaitan dengan lembaga pariwisata jika di daerah tersebut wisatawan dapat merasakan keamanan, (protection of tourism) dan terlindungi maka wisatawan akan semakin sering mengunjungi dan mencari DTW. Hal yang tidak kalah penting dalam konteks pembangunan desa adalah memperhatikan potensi desa, keberhasilan dalam melakukan assesment potensi desa akan berpengaruh pada keberhasilan pembangunan desa. Identifikasi potensi desa dengan benar akan membuat desa menjadi tahu kekuatan yang dimiliki dan layak untuk dikembangkan dan digunakan untuk menangkap peluang yang ada.

Penelitian-penelitian tentang BUMDes dan desa wisata sudah dilakukan oleh beberapa peneliti, antara lain: Arnis Rochma Harani et al. dalam artikelnya melakukan kajian tentang bagaimana desa melakukan analisis akan potensi desanya untuk bisa menjadi desa wisata yang memiliki karakter, penelitian dilakukan di desa Pesantren. Hasil dari kajian ini didapatkan bahwa potensi desa terbukti memiliki potensi untuk dijadikan sebagai desa wisata dan memberikan dampak yang signifikan akan kesejahteraan masyarakat dan juga pembangunan nasional (Harani et al. 2017).

Bahari et al. 2021, melakukan kajian dalam tentang BUMDes dari sudut pandang keberadaan BUMDes sebagai pilar berkembangnya perekonomian lokal yang ada di desa. Hasil dari risetnya didapatkan bahwa keberadaan BUMDes mampu menjadi pilar tumbuhnya ekonomi masyarakat dan berkembang menjadi desa mandiri. Hal ini dapat terwujud dengan adanya penyertaan modal, terserapnya tenaga kerja dan tentunya meningkatkan PAD (Pendapatan Asli Desa) (Utomo, 2021).

Nurul Aeni dalam kajiannya tentang deskripsi kinerja BUMDes di Kabupaten Pati. Hasil kajian di dapatkan, [1] perkembangan BUMDes belum optimal, yang ditunjukkan 
oleh sebagian besar BUMDes berdasarkan kriteria dasar. Simpan pinjam merupakan bidang usaha yang paling luas, sementara hanya beberapa BUMDes yang memiliki potensi desa; [2] kendala pengembangan BUMDes terletak pada semua dimensi pengukuran kinerja, yaitu keterbatasan modal dan kekayaan, pengelolaan dan pelaporan yang berantakan, keberadaan BUMDes yang belum berdampak pada masyarakat desa, kelembagaan yang tidak stabil, tata kelola dan pengembangan perusahaan yang kurang optimal, dan BUMDes, legalitas belum tegas; [3] akar penyebab belum optimalnya pengembangan BUMDes adalah keterbatasan kapasitas pengelola BUMDes, pengaruh konstelasi politik di desa, minimnya dukungan dari pemerintah desa dan pemilihan perusahaan yang tidak memiliki kantor pusat di desa. potensi desa (Aeni, 2020).

Marwah dan Siti Ferbia (2021) melakukan kajian tentang strategi yang dipilih untuk pengelolaan program BUMDes dalam pencapaian kesejahteraan masyarakat dilihat dari sudut pandang ekonomi syariah. Riset dilakukan di Desa Tanjung Lalak Utara. Riset ini disimpulkan beberapa hal penting yaitu: [1] strategi pengelolaan BUMDes untuk kesejahteraan masyarakat dilihat dari indikator kesejahteraan masyarakat yang tidak namun stabil dan merata; [2] jika dilihat dari perspektif ekonomi Islam, strategi pengelolaan BUMdes telah dapat membantu dan menguntungkan sebagian orang karena bisnis penyediaan tabung gas dapat memudahkan masyarakat untuk mendapatkannya. Sebagaimana dijelaskan dalam firman Allah SWT dalam Surah Al Maidah Ayat 2. Kedua strategi ini dipilih oleh pengelola untuk mencapai kesejahteraan dengan memperhatikan syarat dan ketentuan berlaku pada aturan ekonomi syariah (Marwah, 2021).

Oktaviani, dalam kajiannya yang berjudul keterterapan prinsip-prinsip pengendalian internal dalam tata kelola BUMDes di Kabupaten Sidoarjo dihasilkan bahwa implementasi akan prinsip-prinsip pengendalian internal oleh Badan Usaha Milik Desa di Kabupaten Sidoarjo masih variatif. Terdapat dua BUMdes yang tingkat implementasinya masih di bawah 50\%, sedangkan lainnya tingkat implementasinya sudah di atas $70 \%$. Sedangkan tingkat relevansi implementasi kerangka pengendalian internal modifikasi oleh BUMDes di Kabupaten Sidoarjo berada di atas 67\%. Hal ini berarti bahwa peraturan pemerintah tentang tata kelola BUMDes belum mampu memberikan sumbangan pada pengendalian internal yang baik bagi BUMDes, oleh karena itu prinsip-prinsip dalam kerangka pengendalian internal COSO diterapkan oleh BUMDes dengan melakukan modifikasi berdasarkan struktur organisasi dan sumberdaya masing-masing BUMDes (Oktaviani \& Nuswantara, 2020).

Juhro et al. dalam artikelnya kajian yang dilakukan dengan topik bahasan gaya kepemimpinan transformasional dengan kolaborasi katalis secara teoritis mampu memberikan perubahan yang signifikan di wilayahnya. Era industri 4.0 yang saat ini terjadi adalah peluang baik bagi pemimpin untuk melakukan perubahan dengan melibatkan banyak pihak terkait dalam proses pembangunan di daerah. Hal ini merupakan efek dari teknologi yang menyebabkan kemudahan akan akses informasi dan komunikasi dengan orang lain dan banyak pihak. Seorang pemimpin transformasional dengan kompetensi yang dimilikinya diharapkan dapat melakukan kolaborasi katalis untuk melakukan inovasi terhadap kebutuhan daerahnya dan juga proses yang berkelanjutan baik dari aspek ekonomi juga lingkungan. Hasil kajian tema di atas didapatkan hasil bahwa pemimpin harus berani melakukan inovasi dan sangat peduli terhadap pembangunan daerahnya meskipun sumber daya yang ada di sana terbatas. Oleh karena itu pemimpin harus melakukan kolaborasi secara katalis dengan beberapa pihak untuk dapat mengoptimalkan semua peluang yang ada demi kemajuan daerah yang dipimpin (Juhro et al., 2020).

Ismail dalam kajiannya yang berjudul Strategi Pengembangan Pariwisata Provinsi Papua dihasilkan bahwasannya informan yang digunakan dalam kajian ini meliputi unsur perguruan tinggi, Bappeda, Balitbangda, Dinas Pariwisata, Dinas Perindustrian dan Perdagangan, Dinas Pendapatan Daerah, Dinas Tenaga Kerja, Tokoh adat, Tokoh Agama, dan Dinas Koperasi UKM,Dinas Kebudayaan, Dinas Sosial, Dinas Pendidikan dan LSM. Penelitian ini menunjukkan bahwa tata kelola pariwisata di Papua masih dikelola secara tradisional dan dikelola oleh masyarakat adat. Kendala yang dihadapi 
dalam pengelolaan pariwisata di sana adalah belum adanya Rencana Induk Pariwisata Daerah, kurangnya promosi dan keamanan yang belum juga stabil. Sampai saat ini kegiatan wisata hanya kegiatan rutinitas dan belum memberikan dampak ekonomi (efek berganda) sehingga masih membutuhkan strategi pengembangan potensi alam untuk menjaga kelestarian sumberdaya alam dan terjaganya iklim pariwisata yang kondusif. (Ismail, 2020).

Herdiana dalam artikelnya yang berjudul Kecenderungan Perilaku Koruptif Kepala Desa dalam Pembangunan Desa menemukan bahwa perilaku korupsi kepala desa disebabkan oleh tiga faktor utama, yaitu pertama, faktor regulasi dimana UndangUndang Desa memberikan kewenangan yang besar untuk pembangunan kepada kepala pemerintahan desa, sehingga kepala desa menjadi kepala desa di tingkat pusat, tatap muka desa menjadi keseimbangan dan kontrol bagi kepala desa. Kedua, faktor pribadi kepala desa, seperti tekanan ekonomi, keserakahan, integritas dan moralitas yang buruk, serta tuntutan janji politik. Ketiga faktor masyarakat, tidak adanya aturan yang jelas untuk pemantauan yang dapat dilakukan masyarakat untuk mengevaluasi kinerja kepala desa berdampak pada kurangnya kontrol kepala desa. Ketiga faktor tersebut sangat berkontribusi terhadap perilaku koruptif para kepala desa dalam menjalankan tugasnya (Herdiana, 2019).

Yunas, dalam artikelnya yang berjudul Implementasi Konsep Penta Helix Dalam Pengembangan Potensi Desa Melalui Model Lumbung Ekonomi Desa Di Provinsi Jawa Timur. Artikel tersebut secara garis besar menjelaskan model inovasi pengembangan potensi desa sebagai upaya peningkatan kesejahteraan masyarakat desa di Provinsi Jawa Timur berupa Lumbung Ekonomi Desa berkonsep penta helix, mulai dari pemetaan dan pelatihan pengelolaan potensi desa hingga digitalisasi ekonomi pedesaan bagi generasi muda dalam komersialisasi potensi yang telah dikelola (e-nomakaryo dibaca: enom makaryo). Metode yang digunakan adalah deskriptif dan kualitatif. Penelitian dilakukan di tiga desa yaitu Desa Panglungan, Wonosalam, Jombang yang memiliki potensi kopi dan wisata unggulan; Desa Kebonagung, Sawahan, Nganjuk dengan potensi jambu mete dan Desa Made, Kudu, Jombang dengan potensi Gadung. Melalui model ini, pengembangan potensi desa harus berdampak pada kesejahteraan dan kemandirian masyarakat desa (Yunas, 2019).

Kajian yang dilakukan penulis ini tentunya berbeda dengan kajian terdahulu walaupun dengan tema yang sama yaitu meneliti tentang BUMDes, perbedaannya pada fokus kajiannya yaitu kepemimpinan transformasional dan kolaborasi katalis (catalytic collaboration) yang dilakukan oleh Kepala Desa dalam mendorong inovasi pembangunan di desa khususnya pengelolaan Taman Ghanjaran di Desa Ketapanrame, Mojokerto.

Desa Ketapanrame berada di kecamatan Trawas Kabupaten Mojokerto Provinsi Jawa Timur dengan luas desa kurang lebih 345.462 Ha. Desa Ketapanrame memiliki batas wilayah desa yang berbatasan langsung sebelah barat dengan Desa Trawas, sebelah timur dengan Desa Lumbangrejo Kabupaten Pasuruan, Sebelah Utara Desa Kesiman dan Sebelah Selatan Perhutani. Terkait dengan struktur pemerintahannya Desa Ketapanrame terbagi menjadi tiga dusun yaitu, Dusun Ketapanrame, Dusun Sukorame dan Dusun Slepi serta terdiri dari 16 Rukun Warga dan 43 Rukun Tetangga dan memiliki penduduk sebanyak 6.042 Jiwa dengan komposisi berjenis kelamin laki-laki 2.722 orang dan berjenis kelamin perempuan 3.320 orang. Warga Desa Ketapanrame mayoritas beragama Islam sebanyak 6.018 orang, beragama Kristen 15 orang, beragama Katolik 7 orang dan beragama Hindu sebanyak 2 orang. Desa Ketapanrame ini merupakan desa terluas yang ada di Kecamatan Trawas Mojokerto.

Dari aspek hidrologi, di Desa Ketapanrame memiliki tata kendali dan pengaturan tata air yang baik, desa ini memiliki aliran-aliran sungai besar dengan debit air yang cukup besar sebagian sungai-sungai kecil yang berfungsi sebagai irigasi sawah. Secara umum curah hujan cukup tinggi, sehingga kebutuhan air sangat terpenuhi baik air untuk pertanian maupun untuk kebutuhan hidup sehari-hari. Topografis Desa Ketapanrame secara umum termasuk daerah dataran tinggi berdasarkan ketinggian wilayah 8001.000 mdpl dan merupakan wilayah pegunungan Desa Ketapanrame selain memiliki wilayah yang luas juga memiliki pemandangan yang indah karena berada di daerah 
pegunungan. Masyarakat Desa Ketapanrame mayoritas bermata pencaharian pertanian, peternakan dan perdagangan. Letak Desa Ketapanrame tergolong desa yang paling ujung di Kabupaten Mojokerto. Ketiga dusun yang dimiliki masing-masing memiliki sejarah dan asal muasal yang berbeda. Dusun Ketapanrame yang memiliki asal muasal paling tua dibandingkan dengan dusun yang lain. Dengan kearifan lokal para sesepuh pada saat itu ketiga dusun tersebut digabung menjadi satu yaitu dengan nama Desa Ketapanrame, berikut ini asal muasal Desa Ketapanrame. Terciptanya nama dan keberadaan Desa Ketapanrame berawal dari kisah sejarah zaman dahulu diceritakan secara turun temurun oleh para leluhur Desa Ketapanrame bahwa nama Desa Ketapanrame berasal dari kata Pertapaan dan Kata Ramai. Dikisahkan bahwa dulu merupakan suatu wilayah tempat pertapaan yang sangat ramai dikunjungi oleh para pertapa, sejak dari kisah kejadian tersebut sampai saat ini dijadikan simbol atau pengingat oleh warga masyarakat, yang menjadikan asal usul terbentuknya Desa Ketapanrame ini.

Aspek kebaruan yang ingin disajikan dalam artikel ini berdasar dari beberapa artikel sebelumnya dapat dilihat bahwa sebagian besar BUMDes yang seharusnya menjadi entry point terkait dengan kemandirian ekonomi tetapi masih banyak yang belum mampu menemukan unit usaha yang tepat dan berkesan mengikuti tren tanpa ada sebuah kajian terlebih dahulu. Desa Ketapanrame telah menemukan unitunit usaha yang sudah berjalan dengan baik dan mandiri, akan tetapi ada satu unit usaha yang menghasilkan banyak keuntungan adalah Wisata Ghanjaran. Oleh karena itu pada penelitian ini akan dikaji lebih mendalam tentang proses awal, tata kelola dan bagaimana karakter kepemimpinan transformasional dan kolaborasi-kolaborasi katalis yang dilakukan oleh Kepala Desa dalam mendorong keberhasilan pengelolaan Taman Ghanjaran serta berharap kajian ini juga dapat dijadikan rujukan bagi peneliti lain untuk melakukan penelitian tentang pembangunan desa di masa mendatang.

\section{Metode}

Artikel ini merupakan hasil penelitian dengan menggunakan pendekatan kualitatif. Creswell menyatakan penelitian kualitatif merupakan penelitian yang sangat tergantung pada informasi dari informan yang terlibat langsung dalam pembangunan desa. Pengumpulan data dilakukan dengan wawancara, observasi langsung dan dokumen-dokumen yang terkait dengan pembangunan di Desa Ketapanrame. Penggunaan metode kualitatif ini memudahkan penulis dalam mengamati fenomenafenomena yang ada di lapangan, baik yang bersifat alamiah maupun rekayasa manusia, yang lebih menekankan pada karakteristik, kualitas, dan keterkaitan antar kegiatan. Selain itu, melalui Pendekatan kualitatif tersebut diharapkan mampu memperoleh uraian yang lebih luas tentang ucapan, tulisan, atau perilaku yang dapat diamati dari individu, kelompok, masyarakat maupun organisasi tertentu (Creswell, 2008). Dalam mendapatkan data wawancara yang mendalam (in depth interview) pada narasumber dilakukan menggunakan teknik purposive. Terdapat 7 narasumber pada penelitian ini, diantaranya adalah kepala desa, staf BUMDesa, pelaku usaha, dan staf desa. Analisa data yang digunakan adalah metode induktif.

\section{Hasil Dan Pembahasan}

\section{III.1. Inovasi Pembangunan Desa Ketapanrame}

Desa Ketapanrame merupakan desa dengan banyak prestasi yang didapatkan terkait dengan keberhasilan dalam pembangunan desa dan tata kelola Badan Usaha Milik Desa (BUMDesa). Desa Ketapanrame ini dibandingkan dengan desa-desa lain di sekitarnya memiliki potensi yang tidak jauh berbeda, akan tetapi dengan kejelian kepala desa sebagai pemimpin dalam melakukan analisis akan potensi yang dimiliki dan kemampuan merencanakan masa depan membuat desa ini memiliki banyak prestasi. Berikut ini adalah data terkait dengan hasil pertanian dan peternakan yang ada di sana sebagai berikut: 
MATRA PEMBARUAN

Jurnal Inovasi Kebijakan

Tabel 1. Hasil Pertanian dan Peternakan.

Tabel 2. Potensi Sumber Daya Manusia.

Tabel 3. Keadaan Sosial Ekonomi
Inovasi Pembangunan Desa Melalui Kepemimpinan Transformasional Dan Catalytic Collaboration: Belajar Dari Keberhasilan Pengelolaan Taman Ghanjaran Di Desa Ketapanrame, Mojokerto

$\begin{array}{lrr}\text { Hasil Pertanian dan Peternakan } & \text { Luas (HA) } & \begin{array}{c}\text { Hasil } \\ \text { (Ton/ Ha/ Tahun) }\end{array} \\ \text { Hasil Pertanian } & 25 & 10 \\ \text { Padi } & 10 & 20 \\ \text { Jagung } & 10 & 20 \\ \text { Ketela } & 6 & 15 \\ \text { Iles-iles (Lahan perhutani) } & 40 & 1 \\ \text { Kopi (Lahan perhutani) } & 40 & 75 \\ \text { Ashitaba (Lahan perhutani) } & & \\ \text { Hasil Peternakan } & 324 \text { ekor } & \\ \text { Sapi } & 870 \text { ekor } & \\ \text { Kambing } & 20.000 \text { ekor } & \\ \text { Ayam Potong } & & \end{array}$

Sumber: Dokumen desa Ketapanrame, 2020

Dari tabel di atas tergambar bahwa Desa Ketapanrame ini memiliki aneka hasil pertanian dan juga tiga hasil peternakan yang menonjol. Selain itu, pada sudut pandang yang berbeda dari sumber daya manusia yang dibedakan pada kriteria tingkat pendidikan, kader pembangunan desa dan tenaga kesehatan yang ditunjukkan pada tabel berikut ini:

\begin{tabular}{|c|c|c|}
\hline No & Uraian Aspek & Jumlah (orang) \\
\hline \multicolumn{3}{|c|}{ I. Tingkat Pendidikan Penduduk } \\
\hline & Tidak Tamat SD/ belum sekolah & 1.319 \\
\hline & Tamat SD / sederajat & 2.154 \\
\hline & Tamat SMP / sederajat & 1.025 \\
\hline & Tamat SLTA / sederajat & 1.187 \\
\hline & Lulus Akademi / Perguruan Tinggi & 357 \\
\hline \multicolumn{3}{|c|}{ II. Kader Pembangunan Desa } \\
\hline & Jumlah Kader Pembangunan Desa & 5 \\
\hline & Jumlah Kader Pembangunan Desa Aktif & 5 \\
\hline \multicolumn{3}{|c|}{ III. Tenaga Medis dan Paramedis } \\
\hline & Jumlah Bidan & 3 \\
\hline & Kader Kesehatan & 21 \\
\hline & Terlatih & 21 \\
\hline & Tidak Terlatih & 0 \\
\hline
\end{tabular}

Sumber: Dokumen desa Ketapanrame, 2020

Sedangkan terkait dengan mata pencaharian dari warga Desa Ketapanrame dapat dilihat sebagaimana tersaji dalam tabel di bawah ini :

$\begin{array}{lclclc}\text { Mata Pecaharian } & \begin{array}{c}\text { Jumlah } \\ \text { (orang) }\end{array} & \text { Mata Pecaharian } & \begin{array}{c}\text { Jumlah } \\ \text { (orang) }\end{array} & \text { Mata Pecaharian } & \begin{array}{r}\text { Jumlah } \\ \text { (orang) }\end{array} \\ \begin{array}{lcccc}\text { Petani } \\ \text { Buruh Tani }\end{array} & 385 & \text { Pensiunan } & 27 & \text { Tukang Besi/ Pandai Besi } & 5 \\ \text { Buruh Serabutan } & 640 & \text { Tukang Batu } & 23 & \text { Sopir } & 19 \\ \text { Pegawai Negeri Sipil } & 24 & \text { Tukang Kayu } & 37 & \text { Reparasi Sepeda Motor } & 26 \\ \text { dan Mobil } & & \text { Tukang Las } & 717 \\ \text { Pegawai Swasta } & 588 & \text { Tukang Jahit } & 8 & \text { Mebel } & 721 \\ \text { TNI dan Polri } & 15 & \text { Tukang Ojek } & 48 & \text { Pedagang }\end{array}$

Sumber: Dokumen desa Ketapanrame, 2020

Keberhasilan Desa Ketapanrame dalam mengelola BUMDes dapat dilihat dari perkembangan unit-unit usaha yang bertambah dan tidak satupun yang merugi. Berikut ini adalah unit-unit usaha dari BUMDes Desa Ketapanrame: 
Tabel 4. Unit-Unit Usaha BUMDes Desa Ketapanrame dan Tahun Berdirinya

\begin{tabular}{|c|c|}
\hline Tahun Berdiri & Unit Usaha \\
\hline 2001 & Usaha BPAM Tirto Tentrem (lembaga usaha desa) \\
\hline 2010 & $\begin{array}{l}\text { BUMDes Ketapanrame } \\
\text { 1. Pengelolaan Air Minum } \\
\text { 2. Pengelolaan Kebersihan Lingkungan } \\
\text { 3. Pengelolaan Wisata Ghanjaran } \\
\text { 4. Pengelolaan Air Tangki }\end{array}$ \\
\hline 2020 & $\begin{array}{l}\text { 5. Pengelolaan lahan dan kandang ternak } \\
\text { 6. Pengelolaan Simpan Pinjam }\end{array}$ \\
\hline
\end{tabular}

Sumber: Dokumen desa Ketapanrame, 2020

Berdirinya Wisata Ghanjaran yang saat ini merupakan unit usaha yang paling tinggi pendapatannya dalam proses pendiriannya memakan waktu yang lama dan menghadapi beberapa hambatan, seperti yang dikemukakan oleh kepala desa, Zainul Arifin bahwa berdirinya Taman Ghanjaran ini kami berproses sejak tahun 2015. "Kami mulai berpikir tentang tanah ghanjaran karena adanya PP 47 yang mana tanah Ghanjaran tata kelola di bawah kepala desa dari situ kami kemudian berfikir dengan memperhatikan potensi desa kita seharusnya kita bisa menjadi berbeda dengan desa lain dan lebih baik, akhirnya tercetus untuk membuat tempat wisata di tanah Ghanjaran kita. Untuk mewujudkan itu kami rembug dengan BPD melalui Musyawarah desa dan muncul kesepakatan dan akhirnya muncul peraturan-peraturan desa antara lain PERDES NO.10 Tahun 2015: Badan Usaha Milik Desa Ketapanrame, PERDES NO.2 Tahun 2017: Pengelolaan Aset Desa dan PERDES NO.2 Tahun 2019: Pengelolaan sebagian aset desa oleh BUMDesa Ketapanrame dari Peraturan desa itulah kami mulai bergerak dan mencari investor itupun tidak mudah tetapi kami terus berusaha dan meyakini akan berhasil," ujar Zainul.

Merujuk pada kondisi di atas dapat dipahami betapa penting peran kepala desa sebagai pemimpin dalam memberikan arah akan tujuan yang hendak dicapai. Hal ini terkait erat dengan kapasitas yang dimiliki oleh kepala desa dalam manajemen tata kelola desa. Kemampuannya dalam menangkap peluang, memetakan potensi desa dengan perencanaan yang tepat untuk kemajuan desanya. Keberhasilan dalam membuat rencana dan memilih skala prioritas bukan pekerjaan yang mudah tetapi membutuhkan keseriusan dan kejelian dalam memanfaatkan peluang yang ada.

Konsep manajemen kepemimpinan memang memberi penekanan bahwa kompetensi seorang pemimpin yang baik dalam mengelola dan memotivasi sumber daya serta mengoordinasikan perubahan dapat mendorong organisasi atau pemerintahan agar lebih cepat dan efektif dalam mencapai tujuannya. Hal ini ditunjukkan oleh Kepala Desa Ketapanrame yang kemudian membawa Taman Ghanjaran dapat dikelola oleh BUMDes dengan hasil yang baik. Kepala Desa memiliki komitmen yang kuat mengedepankan prinsip transparansi dan akuntabilitas pada pengelolaan Taman Wisata Ghanjaran sehingga masyarakat dapat melihat laporan secara online di WhatsApp Group (WAG) ataupun di website desa. Hal ini senada dengan yang dikemukakan oleh staf BUMDes di mana BUMDes di Desa Ketapanrame dikelola secara transparan dan untuk kesejahteraan warga, warga yang berjualan dipalak-lapak puas begitu pula dengan warga yang bekerja di wahana, di parkir, jaga ponten dan lain-lain, malah pernah ketika wisata ramai sebelum pandemi ponten (kamar mandi) dalam 1 tahun menghasilkan 23 juta belum wahana dan lapak-lapak. Semua laporan keuangan akan terlapor setiap bulan pada tanggal 5 dan para pemilik saham dan pekerja akan mendapatkan transfer pada tanggal 6 di setiap bulannya.

Tata kelola yang transparan ini juga dikemukakan oleh kepala desa, di mana dinyatakan bahwa hasil dari unit-unit usaha itu dalam pengelolaannya selalu transparan bahwa dalam prosentasinya. Adapun persentase adalah sebagai berikut dengan komposisi sebagai berikut: PAD desa maksimal 20\%, operasional BUMDesa maksimal 25\%, dana sosial 5-10\%, dana pengembangan minimal $40 \%$ dan dana cadangan minimal 10\%. Kepala desa juga menyadari bahwa keberadaan Wisata Ghanjaran itu bisa dinikmati hasilnya adalah orang tertentu antara lain kepala desa, pengelola BUMDes, dan penjual di lapak-lapak. Kondisi ini dirasakan tidak adil bagi 
orang-orang yang mampu dan menginginkan juga ikut merasakan keuntungan dari keberadaan Wisata Ghanjaran. Berawal dari itu maka kepala desa berfikir bagaimana cara yang tepat agar keinginan warga tersebut dapat terwujud. Untuk mengakomodasi kelompok tersebut akhirnya Kepala Desa berfikir bagaimana jika Wisata Ghanjaran yang awalnya hanya waterpark dan lapak-lapak ditambah dengan wahana permainan. Wahana ini diwujudkan dengan mengikut sertakan warga yang mampu untuk membeli saham. Saham yang diterbitkan dan ditawarkan ke warga desa dengan ketentuan sebagai berikut: harus warga desa asli (bukan pendatang), pembeli saham belum memiliki usaha, batas maksimal kepemilikan saham adalah 10. Harga per saham adalah 1 juta rupiah. Sampai saat penelitian ini dilakukan saham yang telah terbeli oleh masyarakat sebanyak 3.800 saham.

Manajemen kepemimpinan yang diterapkan oleh Kepala Desa Ketapanrame mengingatkan pada definisi menarik tentang leadership yang dibuat oleh Laurie J. Mullins dalam bukunya yang berjudul Management and Organisational Behaviour. Mullins (2013) menyatakan definisi berikut: "Leadership is about getting people to do willingly, that which their instincts teach them not to do" (kepemimpinan adalah kemampuan membuat orang mau melakukan hal yang secara instingtif tidak ingin mereka lakukan). Definisi ini menarik karena menyiratkan betapa hebatnya peran seorang pemimpin. Ia akan mampu membuat orang lain melakukan apa pun yang sebelumnya tidak mau mereka lakukan (secara instingtif) (Mullins, 2013).

Selain itu, keberhasilan membangun inovasi desa khususnya dalam pengelolaan Taman Ghanjaran di Desa Ketapanrame tidak dapat dilepaskan dari sisi kharismatik dan pendekatan personal yang dilakukan oleh Kepala Desa. Hal tersebut sejalan dengan konsep transformational leadership merupakan jenis kepemimpinan yang lebih memperhatikan unsur karismatik dan afektif kepemimpinan (Nurcholis et al.2016). Popularitas transformational leadership mungkin dikarenakan penekanan pada motivasi intrinsik dan pengembangan oleh pengikutnya dengan menyesuaikan kebutuhan organisasi, terinspirasi dan diberdayakan untuk meraih keberhasilan (Juhro, 2018).

Dalam upaya membangun inovasi yang berkelanjutan, pendekatan yang harus digunakan oleh seorang leader harus semakin lengkap. Salah satu pendekatan yang dapat melengkapi seorang leader dalam menghadapi tantangan yang kompleks ini adalah kolaborasi katalis (catalytic collaboration). Catalytic collaboration merupakan pendekatan baru dalam membentuk transformasi sosial/ekonomi dengan tujuan membantu berbagai organisasi untuk bekerjasama dalam tujuan lebih besar daripada tujuan masing-masing organisasi tersebut. Dalam penerapannya, catalytic collaboration memiliki empat komponen utama, yaitu memprioritaskan pembelajaran, menerapkan cara berpikir dan bertindak yang sistematis, membuka akses sebesarbesarnya atas aset/informasi bersama, serta membangun hubungan jangka panjang yang beraneka ragam dan bersifat transformasional (Juhro, 2018).

Catalytic collaboration menjadi relevan untuk diterapkan karena isu-isu yang muncul semakin hari semakin kompleks. Kolaborasi yang bersifat katalitik menjadi hal yang krusial untuk diterapkan karena memecahkan masalah dengan cara yang bias menjadi kurang efektif. Catalytic collaboration juga berpotensi untuk menyatukan besaran pertumbuhan ekonomi yang terjadi di daerah-daerah sehingga meningkatkan perkembangan ekonomi nasional, bahkan secara global. Selain itu, studi yang dilakukan oleh Zohdy et al. (2016) pada Stanford Social Innovation Review menunjukkan bahwa dampak yang dihasilkan oleh catalytic collaboration merupakan dampak yang jangka panjang dan sustainable. Studi tersebut juga menyatakan bahwa pendekatan ini memiliki potensi yang besar untuk menyelesaikan masalah sosial (Juhro, 2018).

Keberhasilan inovasi pembangunan Desa Ketapanrame khususnya dalam pengelolaan Taman Ghanjaran tentunya tidak lepas dari upaya kerja sama yang ditempuh oleh pemerintah desa. Sejak awal pengelolaan Taman Ghanjaran tersebut, Pemerintah desa telah berkomitmen untuk menjalin kolaborasi yang saling menguntungkan dengan beberapa lembaga antara lain Pengelola wana wisata air terjun Dlundung, PT. cahaya Putra, Bank BNI, Bank BRI dan PT. Telkomsel, dengan kemitraan-kemitraan tentunya akan menambah kemandirian dari unit usaha dalam jangka panjang. 


\section{III.2. Best Practice Keberhasilan Pengelolaan Wisata Ghanjaran}

Pemilihan unit usaha Wisata Ghanjaran di Desa Ketapanrame tidak lepas dari tangan dingin pemimpin/ kepala desa. Kepala Desa Ketapanrame memiliki kemampuan selain manajerial yang bagus juga mampu melakukan assesment pada potensi desanya. Kepala desa mampu mengidentifikasi beberapa aspek dari keunggulan antara lain:

1. Attraction (daya tarik);

Desa Ketapanrame memiliki daya tarik antara lain pemandangan yang indah memiliki hawa yang sejuk karena berada di dataran tinggi.

2. Accessibility (aksesibilitas);

Sarana dan prasarana untuk mencapai lokasi tersedia antara lain jalan yang bagus, transportasi umum juga ada, penerangan jalan tersedia dan tempat parkir luas.

3. Amenities (fasilitas);

Lokasi Wisata Ghanjaran juga dekat dengan hotel, homestay, villa yang memudahkan pengunjung yang ingin bermalam. Selain itu juga tersedia tempat makan, fasilitas belanja oleh-oleh, akses perbankan, sinyal hp, layanan kesehatan tersedia.

4. Ancillary (kelembagaan);

Di Wisata Ghanjaran ini juga aman, masyarakatnya ramah dan memiliki jiwa sosial yang tinggi.

Dari keempat persyaratan tersebut maka Desa Ketapanrame layak dijadikan desa wisata. Namun di sisi lain, permasalahan yang seringkali muncul dalam pembangunan desa adalah lemahnya pemberdayaan masyarakat. Pada Pemberdayaan masyarakat ini masyarakat diajak untuk turut aktif dalam proses pembangunan, masyarakat diminta menjadi subyek dari perubahan yang dilakukan. Pada ilustrasi dibawah ini terdeskripsikan bagaimana proses pemberdayaan masyarakat yang dikemukakan (Nurcholis et al., 2016) sebagai berikut:

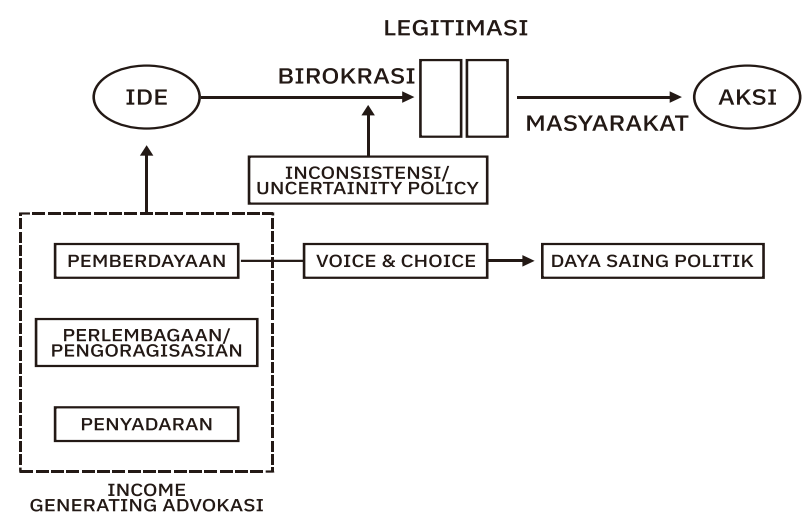

Gambar 1. Alur Proses Pemberdayaan Masyarakat
Gambar: Proses Pemberadyaan Masyarakat

Sumber: Nurcholis, 2016

Keberhasilan tata kelola Wisata Ghanjaran di Desa Ketapanrame ini karena kemampuan pemimpin dalam memberdayakan masyarakat dalam tahapan-tahapan penting mulai merencanakan, melaksanakan, mengelola dan mengawasi. Kepala desa selain menjadi tokoh panutan juga mampu menjadi fasilitator akan visi dan menyadarkan akan pentingnya unit-unit usaha yang tepat untuk meningkatkan kesejahteraan. Selain itu lembaga-lembaga yang ada di sana mulai RT, RW, BPD, tokoh agama, tokoh masyarakat sudah satu pemikiran. Hal ini tentunya akan mempermudah dalam membuat sebuah unit usaha. Hal ini sesuai dengan konsep pembangunan yang saat ini paling banyak digunakan dan dianggap sebagai konsep yang paling relevan adalah konsep pembangunan berbasis masyarakat, atau dengan kata lain pembangunan yang dilakukan oleh masyarakat. Jadi masyarakat dianggap sebagai sebuah subjek penting dari pembangunan, merekalah yang tahu pasti apa yang dibutuhkan, memiliki potensi apa dan kapan waktu yang tepat untuk dilakukan pembangunan. Masyarakat aktif mulai identifikasi masalah, merencanakan, 
melaksanakan, mengevaluasi dan memanfaatkan hasil pembangunan tersebut. Konsep pembangunan ini biasa kita kenal dengan pembangunan berbasis partisipasi ataupun bisa juga dengan pemberdayaan masyarakat yang keduanya condong ke yang bersifat horizontal/ bottom up. Konsep pembangunan dari bawah ini / bottom up banyak dipilih dibandingkan konsep pembangunan dari atas (top-down). Pada konsep pembangunan dari atas (top-down) pemegang kekuasaan (pemerintah) menduduki posisi yang sentral mulai perencanaan (apa yang hendak dibangun) sampai pelaksana pemerintah yang memegang kendali, masyarakat ditempatkan sebagai objek pembangunan.

Dengan kepemimpinan transformasional dan kolaborasi katalis yang dijalankan, Kepala Desa juga berhasil dalam meningkatkan partisipasi masyarakat pada berbagai proses pengambilan keputusan. Secara teoritis partisipasi masyarakat itu dapat diwujudkan jika ada pertama kesempatan, dari aspek ini kepala Desa Ketapanrame mampu memberikan kesempatan kepada banyak pihak untuk ikut serta mulai dari merencanakan Wisata Ghanjaran ini dengan lahirnya perdes-perdes di atas, juga dalam merencanakan melalui musdes-musdes juga dilakukan terbuka dan melibatkan semua pihak. Keterbukaan Informasi ini memberikan kesempatan yang seluasluasnya kepada banyak pihak untuk turut berpartisipasi. Kedua, kemampuan, dalam poin ini tergambarkan bahwa kepala desa mampu melakukan sebuah identifikasi yang baik akan peluang untuk membuat sebuah unit usaha yang akan membawa dampak perekonomian pada banyak orang. Hal ini juga disertai sebuah keyakinan akan potensi kemampuan yang dimiliki selain alam juga kemampuan warganya dalam mengelola atau turut serta dalam unit usaha ini. Ketiga, kemauan, dari aspek ini juga tergambar bahwa ketokohan dari kepala desa Ketapanrame yang tegas, transparan dan jujur membuat warga juga terdorong untuk meneladaninya. Nilai-nilai positif yang ada pada diri kepala desa telah mampu membuat warga memiliki sikap percaya diri dan mandiri.

Ketiga aspek di atas mulai dari adanya kesempatan, tersedianya kemampuan dan mau turut serta mampu tumbuh atau lahir karena kepercayaan masyarakat pada pemimpinnya yang dalam hal ini adalah kepala desa. Bahkan kepala desa Ketapanrame dalam pencalonannya tidak pernah mengeluarkan uang selain untuk pendaftaran. Kepedulian dan kepekaan yang dimilikinya serta ditambah dengan kemampuan konseptual, technical dan manajerial menjadikan Wisata Ghanjaran ini maju dan berkembang bahwa sampai mendapatkan penghargaan-penghargaan di tingkat Provinsi maupun nasional salah satunya BUMDes terbaik Provinsi Jawa Timur tahun 2020 dan peraih program CSR Astra Internasional yang menyisihkan 750 desa se-Indonesia.

\section{Kesimpulan}

Keberhasilan inovasi pembangunan desa Ketapanrame, Mojokerto khususnya dari Unit Usaha BUMDEs Taman Wisata Ghanjaran sampai mendapatkan penghargaan baik di tingkat lokal, Provinsi sampai dengan nasional tidak lepas dari manajemen kepemimpinan transformasional yang dimiliki oleh kepala desa. kepala desa Ketapanrame memiliki peran yang sentral mulai dari perencanaan (bersama BPD melahirkan perdes-perdes terkait tata kelola aset desa), melakukan assesment pada potensi desa, sampai dengan keberhasilan memberdayakan masyarakat dengan terus meningkatnya partisipasi banyak pihak. Ketokohan kepala desa juga menjadi tauladan masyarakat luas dengan nilai-nilai yang dimilikinya antara lain jujur, terbuka, peduli terhadap sesama, tanggung jawab dan amanah.

Dalam upaya membangun inovasi yang berkelanjutan, pendekatan yang harus digunakan oleh seorang leader harus semakin lengkap dengan kolaborasi katalis (catalytic collaboration). Kolaborasi katalis tersebut juga dilakukan oleh kepala desa untuk terus mengembangkan inovasi dan keberlanjutan pengelolaan Taman Ghanjaran melalui kolaborasi dengan berbagai pihak mulai dari sektor swasta, perguruan tinggi hingga media. 


\section{Daftar Referensi}

Aeni, N. (2020). GAMBARAN KINERJA BADAN USAHA MILIK DESA (BUMDES) DI KABUPATEN PATI. https:// doi.org/10.36762/jurnaljateng.v18i2.826

Ariyanto. (2005). Ekonomi Pariwisata. Rineka Cipta.

Coleman, J. (1998). Social Capitalin The Creation of Human Capital. Journal.Unchicago.Edu. https://www. journals.uchicago.edu/doi/pdf/10.1086/228943

Creswell, J. W. (2008). Educational Research: Planning, Conducting, and Evaluating Quantitative and Qualitative Research. Pearson/Merrill Prentice Hall. http://repository.unmas.ac.id/medias/journal/EBK00121.pdf

Fukuyama. (2001). Social Capital and development: The Coming Agenda" Makalah pada Konperensi”Social Capita and Proverty Reduction In Latin America and The Caribbean: Toward a New Paradigm.

Harani dkk, A. R. (2017). PEMETAAN POTENSI DESA MENUJU DESA WISATA YANG BERKARAKTER (Study kasus: Desa Pesantren Kec Ulujami Kab Pemalang). 17. https://ejournal.undip.ac.id/index.php/modul/ article/view/17530

Hasbullah, J. (2006). Social Capital (Menuju Keunggulan Budaya Manusia Indonesia). MR-United Press; Jakarta. https://digilib.umk.ac.id/index.php?p=show_detail\&id=3181

Herdiana, D. (2019). Kecenderungan Perilaku Koruptif Kepala Desa dalam Pembangunan Desa. Matra Pembaruan: Jurnal Inovasi Kebijakan, 3(1), 1-11. https://doi.org/10.21787/mp.3.1.2019.1-11

Ismail, M. (2020). Strategi Pengembangan Pariwisata Provinsi Papua. Matra Pembaruan: Jurnal Inovasi Kebijakan, 4(1), 59-69. https://doi.org/10.21787/mp.4.1.2020.59-69

Juhro, S. M. (2018). Transformational Leadership: Konsep, Pendekatan dan Implikasi Pada Pembangunan. In Радіоелектроніка, Інформатика, Управління (1st ed., Issue 1 (15)). Bank Indonesia Institute. https://docplayer.info/145734769-Leadership-transformational-konsep-pendekatan-dan-implikasipada-pembangunan-chapter-i-only.html

Juhro, S. M., Aulia, A. F., Hadiwaluyo, D., Aliandrina, D., \& Lavika, E. (2020). The Role of Catalytic Collaboration in Leveraging Transformational Leadership Competencies to Generate Sustainable Innovation. International Journal of Organizational Leadership, 9(1), 48-66. https://doi.org/10.33844/ ijol.2020.60490

Marwah, siti F. (2021). Strategi Pengelolaan Program Badan Usaha Milik Desa (BUMDES) Untuk Kesejahteraan Masyarakat Dalam Perspektif Ekonomi Islam (Studi Pada Desa Tanjung Lalak Utara). http://eprints.uniska-bjm.ac.id/id/eprint/4214

Mullins, L. J. M. (2013). Management \& organisational behaviour (10th ed.). ebook. http://www.mim.ac.mw/ books/Management\%20\&\%200rganizational\%20Behaviour,\%207th\%20edition.pdf

Nurcholis dkk, H. (2016). Pembangunan Masyarakat Desa dan Kota (3rd ed.).

Oktaviani, L., \& Nuswantara, D. A. (2020). Keterterapan Prinsip-Prinsip Pengendalian Internal dalam Tata Kelola Badan Usaha Milik Desa (BUM Desa) di Kabupaten Sidoarjo. Matra Pembaruan: Jurnal Inovasi Kebijakan, 4(2), 83-92. https://doi.org/10.21787/mp.4.2.2020.83-92

Putnam, R. (2002). Bowling Alone: The Collapse and Revival of American Community. News Journal. https:// doi.org/10.1016/S0362-3319(02)00190-8

Utomo, B. W. (2021). POTRET BADAN USAHA MILIK DESA (BUMDES) SEBAGAI PILAR PENGEMBANGAN EKONOMI LOKAL DESA. 1, 1. http://conference.um.ac.id/index.php/esp/article/view/628

Yunas, N. S. (2019). Tampilan Implementasi Konsep Penta Helix dalam Pengembangan Potensi Desa melalui Model Lumbung Ekonomi Desa di Provinsi Jawa Timur. 3. https://doi.org/10.21787

Zohdy, N. (2016). Why and How Do Non Profits Work Together. Philantropy News.Org. https:// philanthropynewsdigest.org/columns/the-sustainable-nonprofit/why-and-how-do-nonprofits-worktogether 